\title{
PRECURSORS OF RIBOSOMAL RNA IN YEAST NUCLEUS
}

\author{
Biosynthesis and Relation to Cytoplasmic Ribosomal RNA \\ W. W. SILLEVIS SMITT, J. M. VLAK, R. SCHIPHOF and Th. H. ROZIJN \\ Laboratory for Physiological Chemistry, The State University, Utrecht, The Netherlands
}

\begin{abstract}
SUMMARY
In vivo methylated precursors of ribosomal RNA in yeast have been characterized on acrylamide gels. The initial ribosomal precursor in the yeast nucleus is a 37S RNA component, which is processed to a nuclear 28S RNA. Both the 37S and the 28S RNA components are important constituents of the yeast nucleus. A possible 33S RNA intermediate has been observed. Newly formed 18S rRNA rapidly enters the cytoplasm, while newly formed 26S rRNA appears later. The $26 \mathrm{~S}$ rRNA is most probably formed from the nuclear $28 \mathrm{~S}$ RNA.
\end{abstract}

Evidence has come from several sources that in yeast, as in higher eukaryotes, ribosomal RNA is synthesized via large precursor molecules [1-3]. In a previous publication [3] we have established that the large precursors of ribosomal RNA are located exclusively within the yeast nucleus. Sucrose gradient analysis of nuclear RNA, labelled with radioactive uracil, has revealed that the initial step in the formation of ribosomal RNA is the formation of a $37 \mathrm{~S}$ molecule which is converted into a nuclear 28S RNA. This $28 \mathrm{~S}$ ribosomal precursor RNA is probably an intermediate in the formation of the $26 \mathrm{~S}$ cytoplasmic ribosomal RNA [3]. Little or no newly formed $18 \mathrm{~S}$ ribosomal RNA is associated with the nuclei. The cytoplasmic $18 \mathrm{~S}$ RNA seems to be labelled earlier than the cytoplasmic 26S RNA. Apparently the $18 \mathrm{~S}$ RNA leaves the nucleus almost as soon as it is formed.

In the experiments with radioactive uracil [3] all species of RNA become labelled. This interferes to a certain extent with the estima$3-721803$ tions of the radioactivity associated with ribosomal RNA (rRNA). The use of methyllabelled methionine makes it possible to discriminate between rRNA and heterogeneous RNA, since rRNA, its nuclear precursors and tRNA are the only methylated species of RNA [2-7]. A kinetic study of the methylation in vivo of rRNA in yeast is presented in this paper. Acrylamide gel electrophoresis [8] has been used to study in more detail the relation between nuclear rRNA precursors and cytoplasmic rRNA.

\section{MATERIALS AND METHODS}

\section{Organism and isotope}

The experiments were performed with spheroplasts [9] of the yeast strain Saccharomyces carlsbergensis, no. 74 from the British National Collection of Yeast Cultures. The spheroplasts were incubated $\left(27^{\circ} \mathrm{C}\right)$ at a cell density of $7 \times 10^{7} / \mathrm{ml}$ in a medium containing per $\mathrm{ml} 120 \mathrm{mg}$ mannitol, $10 \mathrm{mg}$ glucose, $0.2 \mu \mathrm{g}$ of resp. thiamine $\mathrm{HCl}$, riboflavin phosphate, nicotinamide, pyridoxal $\mathrm{HCl}$, calcium pantothenate, biotin and inositol, $15 \mu \mathrm{M}\left(\mathrm{NH}_{4}\right)_{2} \mathrm{SO}_{4}, 1 \mu \mathrm{M} \mathrm{MgCl}$ and $20 \mu \mathrm{M}$ sodium-potassium phosphate, pH 6.3. After preincubation for $15 \mathrm{~min}{ }^{\mathrm{a}} \mathrm{H}-\mathrm{Me}-\mathrm{methionine}$ (spec. 
act. 5.4 Ci/mM; Philips Duphar) was added to make a final concentration as given in the legends of figs 2 and 3 . Incubation was then continued for different periods of time. After the labelling, the spheroplast suspensions were rapidly chilled and the spheroplasts were then harvested by centrifugation at $3000 \mathrm{~g}$ for $5 \mathrm{~min}$, at $2^{\circ} \mathrm{C}$.

\section{Preparation of nuclei}

The nuclei were isolated as described previously [9] with a few modifications. The $\mathrm{Mg}$ concentration in the homogenization medium was raised from $0.5 \mathrm{mM}$ to $1.0 \mathrm{mM}$, because at the lower $\mathrm{Mg}$ concentration the nuclei showed a tendency to swell. In the later stages of the isolation procedure the $\mathbf{M g}$ concentration of $0.5 \mathrm{mM}$ could be maintained. The purification of the isolated nuclei was slightly modified. The discontinuous sucrose gradient consisted of the following layers from bottom to top: $2.0 \mathrm{ml} 2.0 \mathrm{M}, 1.0 \mathrm{ml}$ $1.8 \mathrm{M}$ and $1.0 \mathrm{ml} 1.5 \mathrm{M}$ sucrose, all in "PVP medium": $8 \%$ polyvinylpyrrolidone (mol. wt 40000 ) $-0.5 \mathrm{mM}$ $\mathrm{MgCl}_{\mathrm{g}}-0.02 \mathrm{M}$ potassium phosphate, $\mathrm{pH}$ 6.5. One $\mathrm{ml}$ of a suspension of crude nuclei in a $0.6 \mathrm{M}$ solution of sucrose in PVP medium was layered on top of this gradient.

The gradient was centrifuged in a Spinco SW 39 rotor at $39000 \mathrm{rpm}$ for $90 \mathrm{~min}$ at $2^{\circ} \mathrm{C}$. The chemical composition of the crude and purified nuclear preparations was the same as described previously [9, 10].

\section{Preparation of $R N A$}

RNA was extracted essentially as described by Parish \& Kirby [11]. Unless mentioned otherwise all operations were carried out at $4^{\circ} \mathrm{C}$. To extract RNA from spheroplasts and isolated nuclei, the pellets were suspended in $0.01 \mathrm{M}$ sodium acetate buffer, pH 5.1, containing $0.02 \%$ polyvinylsulfate. The suspension of nuclei $\left(2 \times 10^{8}\right)$ was treated with $100 \mu \mathrm{g}$ DNase (Worthington, RNase free) for $12 \mathrm{~min}$ at $27^{\circ} \mathrm{C}$. To extract cytoplasmic RNA an aliquot of the cytoplasmic fraction remaining after the isolation of nuclei was taken. All suspensions were made $1 \%(\mathrm{w} / \mathrm{v})$ in tri-isopropylnaphthalenesulphonate (TIPNS) (Kodak Ltd., Kirkby, Liverpool, T3513), $6 \%(\mathrm{w} / \mathrm{v})$ in 4aminosalicylate (PAS), $6 \%(\mathrm{v} / \mathrm{v})$ in 2-butanol, and were then shaken with an equal volume of phenol$m$-cresol mixture [11], for $10 \mathrm{~min}$ at $20^{\circ} \mathrm{C}$. The phases were separated by centrifugation. The phenolphase and interphase were reextracted together with an equal volume of a solution containing $1 \%$ TIPNS, $6 \%$ PAS and $6 \%$ 2-butanol. The combined waterphases were made $3 \%$ with respect to $\mathrm{NaCl}$ and the phenol extraction was repeated as described above. RNA was then precipitated by the addition of $\mathbf{2 . 5}$ vol $96 \%$ ethanol containing $2 \%$ potassium acetate. After storage overnight at $-20^{\circ} \mathrm{C}$, the precipitated RNA was washed twice with $75 \%$ ethanol containing $0.1 \mathrm{M} \mathrm{NaCl}$ [12]. The RNA from spheroplasts and cytoplasmic fractions was treated with $\mathrm{LiCl}$ according to Schweizer et al. [13] in order to remove tRNA, which was highly labelled.

RNA from spheroplasts and nuclei was prepared for gel electrophoresis according to Loening [14]. Cytoplasmic RNA was prepared for sucrose gradient centrifugation as described previously [3].

\section{Electrophoresis}

Acrylamide gel electrophoresis was performed according to Loening [15] and Bishop et al. [16]. The polymerizing mixture was made $2.4 \%(\mathrm{w} / \mathrm{v})$ in acrylamide and $0.12 \%(\mathrm{v} / \mathrm{v})$ in ethylene diacrylate [17]. The electrophoresis buffer ( $\mathrm{E}$ buffer) contained $0.04 \mathrm{M}$ Tris, $0.02 \mathrm{M}$ sodium acetate and $0.001 \mathrm{M}$ EDTA, adjusted to $\mathrm{pH} 7.4$ with glacial acetic acid [16]. The gels $(0.8 \mathrm{~cm}$ diameter $)$ were treated with $\mathrm{E}$ buffer containing $0.2 \%$ recrystallized sodium dodecylsulfate according to Bishop et al. [16]. The RNA sample contained 10-20 $\mu \mathrm{g}$ RNA dissolved in 10-20 $\mu \mathrm{l} 1 / 4 \mathrm{E}$ buffer $5 \%$ sucrose. Electrophoresis was performed in a Canalco apparatus at $20-25^{\circ} \mathrm{C}$. Further conditions are given in the captions to the figures. After electrophoresis the gels were scanned at $266 \mathrm{~nm}$ in Zeiss spectrophotometer (slit $0.1 \times 0.4 \mathrm{~cm}$ ), that was adapted for this purpose [18] and combined with a Beckman recorder. The gel was then frozen on dry ice and was cut into $0.1 \mathrm{~cm}$ slices. These were solubilized in 0.5 $\mathrm{ml} 1 \mathrm{~N} \mathrm{NH} \mathrm{H}_{4} \mathrm{OH}$ in a scintillation vial for $2 \mathrm{~h}$ at $20-25^{\circ} \mathrm{C}$ [17]. For radioactivity measurements $14.5 \mathrm{ml}$ of a $6: 23(\mathrm{v} / \mathrm{v})$ mixture of Triton $\mathrm{X}-100$ and a toluene solution of PPO and POPOP [19] was added. This mixture is homogeneous at $3^{\circ} \mathrm{C}$ and has a counting efficiency for ${ }^{3} \mathrm{H}$ of $33 \%$ and for ${ }^{14} \mathrm{C}$ of $46 \%$. Radioactivity was measured in a Mark $I$ liquid scintillation counter (Nuclear-Chicago).

The denomination of the different RNA species by $S$ values has been maintained in acrylamide gel electrophoresis. The relationship between $S$ values and migration distance of RNA on acrylamide gels, as given by Lewicki \& Sinskey [20], has been applied to our gels. The two species of rRNA, i.e. 26S and $18 \mathrm{~S}$, have been used as internal standards (see also next section). The $S$ values of the nuclear ribosomal precursors, found by gel electrophoresis, were the same as those found by sucrose gradient analysis [3] i.e. $37 \mathrm{~S}$ and $28 \mathrm{~S}$.

\section{Sucrose density gradient centrifugation}

The procedure has been described previously [3]. One modification was introduced. After cêntrifugation the gradient was displaced from below and the extinction was continuously monitored at $260 \mathrm{~nm}$ in a Zeiss spectrophotomeler combined with a Beckman recorder. Fractions of $0.65 \mathrm{ml}$ were collected in liquid scintillation vials. Radioactivity was measured as described above.

The sedimentation coefficients of RNA for use as internal standards in sucrose gradient and electrophoretic analyses, were determined in a Spinco model $\mathrm{E}$ analytical ultracentrifuge equipped with an ultraviolet optical system with photo-electric scanner. The analyses were carried out using a double sector cell at $44770 \mathrm{rpm}$ in an AN-D rotor. Concentrations of RNA used for sedimentation were within the range of $35-40 \mu \mathrm{g} / \mathrm{ml}$ in a $0.01 \mathrm{M}$ sodium acetate 
buffer, pH 5.1, containing $0.1 \mathrm{M} \mathrm{NaCl}$ and $0.001 \%$ polyvinylsulfate. The sedimentation coefficients were corrected in the usual way to obtain $\mathbf{S}_{\mathbf{2 0}}$, values.

\section{Determination of the specific activity of the} extracted RNA

The procedure for the determination of the specific activity was as described previously [3] with one modification: the radioactivity measurements were carried out as described above.

\section{RESULTS}

\section{Electrophoretic analysis of nuclear and cytoplasmic $R N A$}

The results of an electrophoretic analysis on acrylamide gels of the RNA from the cytoplasmic and the purified nuclear fractions are depicted in fig. 1. The optical density (OD) profile of the cytoplasmic RNA (fig. $1 B$ ) shows the two normal classes of rRNA as two narrow peaks fully separated from each other. The ratio of total OD of $26 \mathrm{~S}$ RNA to that of 18S RNA is 2.0. The OD profile of the nuclear RNA shows, in better resolution, the same RNA components as found in sucrose gradient analysis [3]: a $37 \mathrm{~S}$, a $26 \mathrm{~S}$ and an $18 \mathrm{~S}$ peak. It has been shown previously [3] that the mature rRNA that is present in the nuclear preparations originates mainly from perinuclear ribosomes. It is clear, however, from fig. $1 A$, that the $26 \mathrm{~S}$ peak is disproportionately large compared with the $18 \mathrm{~S}$ peak. The ratio of total OD of 26S RNA to that of 18S RNA in fig. $1 \mathrm{~A}$ is 3.8. This indicates that about $50 \%$ of the $\mathrm{OD}$ in the $26 \mathrm{~S}$ region does not originate in the perinuclear ribosomes. Previously we have shown [3] that there is a relatively large pool of nuclear $28 \mathrm{~S} \mathrm{RNA.} \mathrm{It} \mathrm{is} \mathrm{reasonable} \mathrm{to}$ assume that in our nuclear preparations this 28S RNA species accounts for most of the RNA in the ' $26 \mathrm{~S}$ ' peak that does not originate in perinuclear ribosomes. Attempts to resolve this composite ' $26 \mathrm{~S}$ ' peak into more components by extending the time of electrophoresis were unsuccessful.

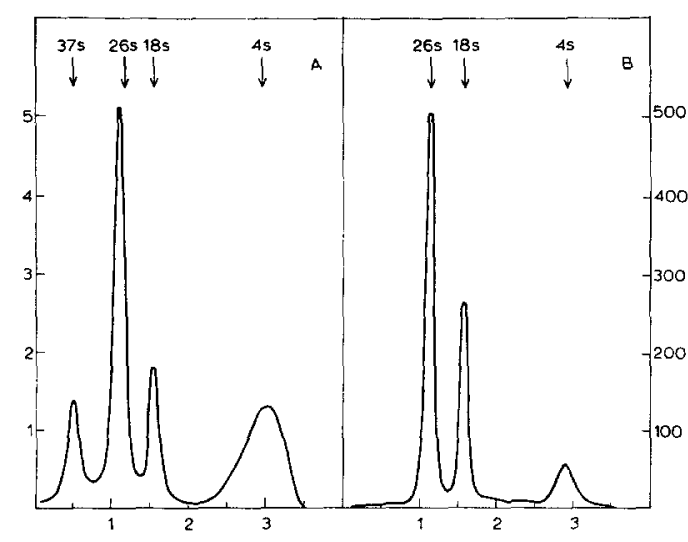

Fig. 1. Abscissa: cm travelled; ordinate: $A_{28 \theta}$. Acrylamide gel electrophoretic analysis of nuclear RNA $(A)$ and cytoplasmic RNA (B). Electrophoresis was for $90 \mathrm{~min}$ at $5 \mathrm{~mA}$ per gel. The OD in the $4 \mathrm{~S}$ region $(A)$ is due to degraded DNA. The OD measured in the analysis of the nuclear and cytoplasmic RNA are converted to values such that both diagrams $(A, B)$ represent the same number of spheroplasts $\left(1.4 \times 10^{9}\right)$.

\section{Ribosomal precursor RNAs in yeast}

In order to obtain a complete picture of the ribosomal precursors in yeast an experiment was designed in which the RNA was isolated directly from the spheroplasts, thus avoiding degradation that might occur during cell fractionation. After short periods of incorporation of ${ }^{3} \mathrm{H}$-Me-methionine, RNA was extracted as described in Materials and Methods. tRNA was removed from the isolated $\mathrm{RNA}$ by means of a $\mathrm{LiCl}$ fractionation. The specific radioactivity of the resulting RNA preparations was at least 1000 $\mathrm{dpm} / \mu \mathrm{g}$, which is sufficient to permit analysis of the labelled RNA by means of acrylamide gel electrophoresis.

Within the time course of the experiments the total radioactivity in the RNA increased linearly with an initial delay of $\frac{1}{2}-1 \mathrm{~min}$, suggesting that the equilibration of the methyl donor pool is very fast. The radioactivity profile of a $5 \mathrm{~min}$ pulse (fig. $2 A$ ) shows a prominent $37 \mathrm{~S}$ peak and a $28 \mathrm{~S}$ peak with a shoulder in the $26-28 \mathrm{~S}$ region. A small 


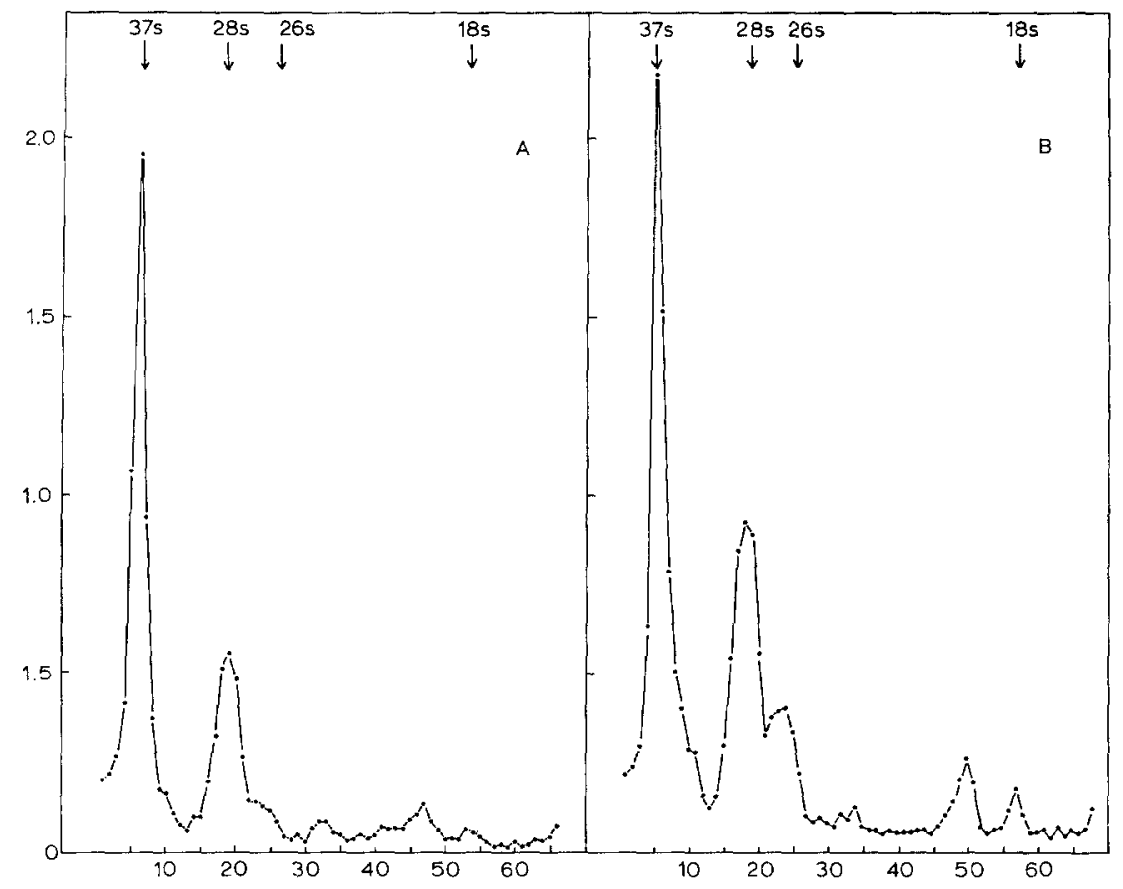

Fig. 2. Abscissa: slice number; ordinate $\mathrm{dpm} \times 10^{-3}$.

Acrylamide gel electrophoretic analysis of spheroplast RNA after a 5 min pulse $(A)$ and a 10 min pulse (B) with ${ }^{3} \mathrm{H}$-Me-methionine (final conc. $40 \mu \mathrm{Ci} / \mathrm{ml}$ ). Electrophoresis was for $6 \mathrm{~h}$ at $5 \mathrm{~mA}$ per gel. One $\mu \mathrm{g}$ of spheroplast RNA, labelled with ${ }^{14} \mathrm{C}$-uracil to a spec. act. of $10000 \mathrm{dpm} / \mu \mathrm{g}$, was added as a marker to determine the position of $26 \mathrm{~S}$ and $18 \mathrm{~S}$ RNA in the gels. The radioactivities measured in the analysis of the spheroplast RNA are converted to such values that both diagrams $(A, B)$ represent the same number of spheroplasts $\left(0.7 \times 10^{7}\right)$. Due to a new batch of ethylene diacrylate, the concentration of ethylene diacrylate in this experiment had to be increased to $0.22 \%(\mathrm{v} / \mathrm{v})$ to ensure sufficient rigidity of the gels.

peak of 18S RNA can also be observed. In between the 26S and the 18S RNA a species of methylated RNA migrates to which an approximate $S$ value of $20 \mathrm{~S}$ can be assigned.

Extension of the labelling period to 10 min results in an increase in the radioactivity of the $18 \mathrm{~S}, 20 \mathrm{~S}, 26 \mathrm{~S}$ and $28 \mathrm{~S}$ RNA species. The radioactivity in the $37 \mathrm{~S}$ peak does not increase appreciably, however. The 20S RNA could be an intermediate in the formation of 18S RNA. Such an intermediate in the processing of rRNA has been described in HeLa cells [8]. There may be still another intermediate RNA component in the $33 \mathrm{~S}$ region that presents itself as a small shoulder.

It is clear from fig. 2 that the main rRNA precursors in yeast are $37 \mathrm{~S}$ and $28 \mathrm{~S}$ RNA molecules. This outcome is in complete agree- ment with the results of the sucrose gradient analysis of RNA from isolated nuclei [3].

\section{A kinetic study of the methylation of} ribosomal $R N A$

In order to study the kinetics of methylation of nuclear and cytoplasmic RNA, spheroplasts were labelled with ${ }^{3} \mathrm{H}-\mathrm{Me}-$ methionine. Short pulses were chosen as it is clear from our data presented in the preceding section that radioactivity appears very early in $26 \mathrm{~S}$ and $18 \mathrm{~S}$ rRNA. The results are given in the following.

\section{Labelling kinetics of ribosomal RNA in the nucleus}

The nuclear RNA has been analysed on acrylamide gels. The results of short periods 


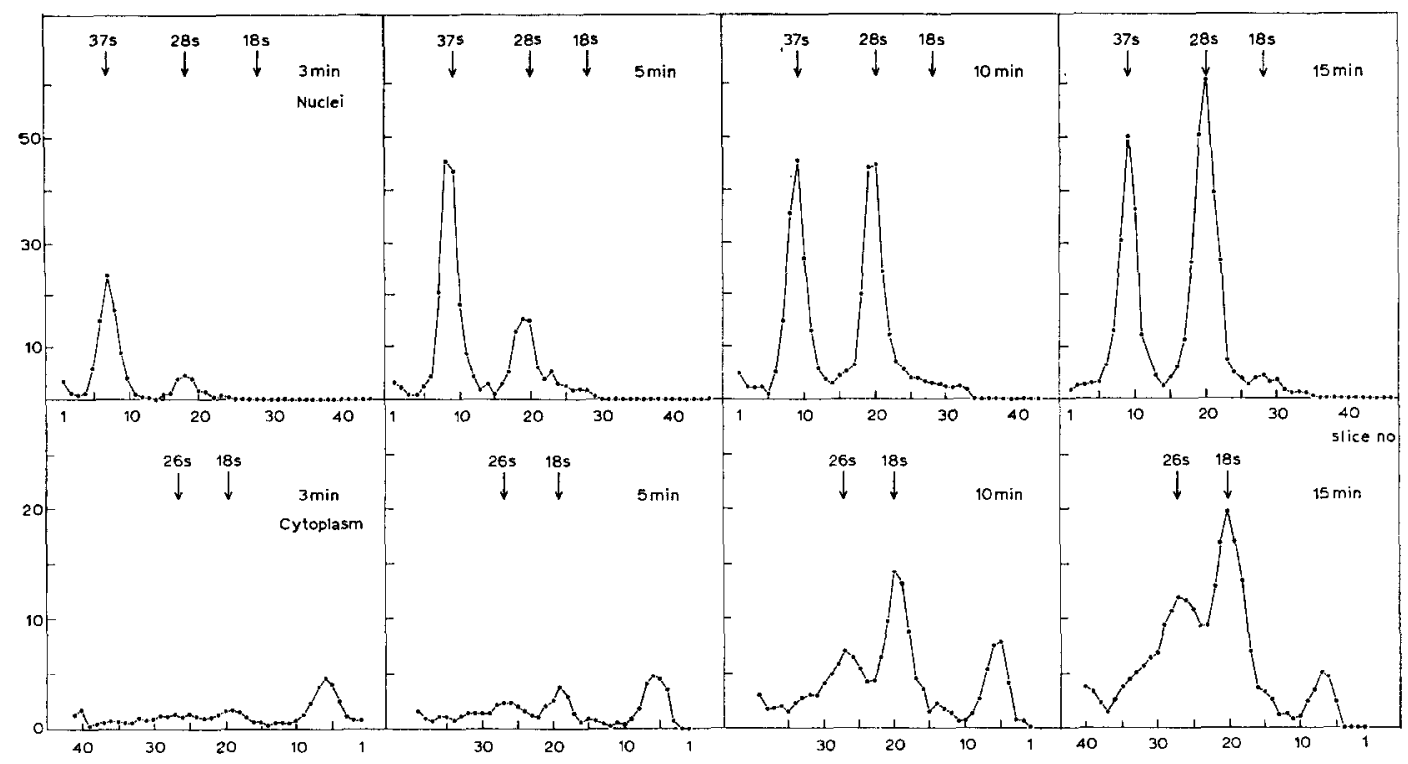

Fig. 3. Abscissa: (top) slice number; (bottom) fraction number; ordinate: $\mathrm{dpm} \times 10^{-3}$.

Acrylamide gel electrophoretic analysis of nuclear RNA (top) and sucrose gradient analysis of cytoplasmic RNA (bottom) after labelling for various times with ${ }^{~} \mathrm{H}-\mathrm{Me}$-methionine (final conc. $7.5 \mu \mathrm{Ci} / \mathrm{ml}$ ). Electrophoresis was for $3 \mathrm{~h}$ at $5 \mathrm{~mA}$ per gel. Centrifugation was for $22 \mathrm{~h}$ at $20000 \mathrm{rpm}$ at $2^{\circ} \mathrm{C}$. The radioactivities measured in the analysis of nuclear and cytoplasmic RNA are converted to such values that all diagrams represent the same number of spheroplasts $\left(1.4 \times 10^{\circ}\right)$. The S-values were deduced from the OD profiles (not shown).

of incorporation of the labelled methylmoiety into nuclear RNA are shown in fig. 3 . After a $3 \mathrm{~min}$ pulse a prominent $37 \mathrm{~S}$ peak has appeared. The 37S RNA is apparently the first methyl-labelled species in the nucleus. Some radioactivity is associated with the 28S RNA. After $5 \mathrm{~min}$ of incorporation radioactivity has increased in both components. From $5 \mathrm{~min}$ on the labelling of the 37S RNA precursor does not increase appreciably, while there is still a progressive accumulation of radioactivity in the $28 \mathrm{~S}$ RNA. The sequential labelling of $37 \mathrm{~S}$ and 28S RNA is clearly shown in fig. 4. No appreciable radioactivity is observed in the $18 \mathrm{~S}$ region in any of the radioactivity profiles of nuclear RNA presented in fig. 3. This indicates that, at least within the time of measurement, no newly formed $18 \mathrm{~S}$ rRNA is associated with the nucleus.

\section{Labelling kinetics of ribosomal RNA in the cytoplasm}

The cytoplasmic RNA has been analysed on sucrose gradients. The low specific activity of the cytoplasmic RNA, after the short pulses applied, makes an analysis on acrylamide gels impossible. The results of the incorporation of the labelled methyl-moiety into cytoplasmic rRNA is shown in fig. 3. After a 3 min pulse the sedimentation profile shows some remnants of labelled tRNA, not removed by the $\mathrm{LiCl}$ fractionation. Some radioactivity is already associated with the $18 \mathrm{~S}$ region of the gradient. There is virtually no radioactivity associated with the $26 \mathrm{~S}$ region of the gradient. From $5 \mathrm{~min}$ on radioactivity accumulates in both the $18 \mathrm{~S}$ and the $26 \mathrm{~S}$ region of the sedimentation profiles. It is clear that during the time of measurement there is more radioactivity associated with 


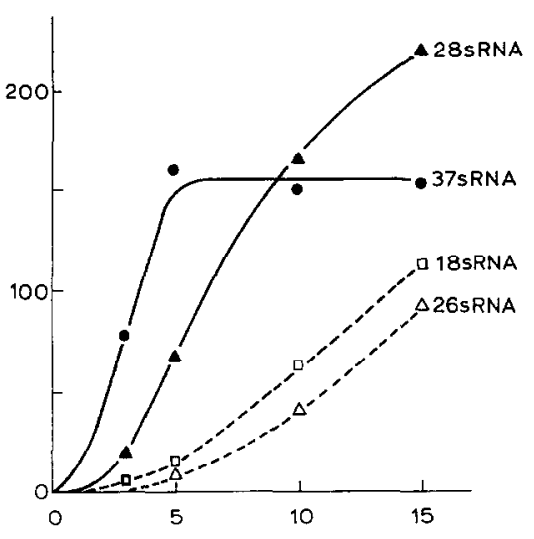

Fig. 4. Abscissa: min; ordinate: $\mathrm{dpm} \times 10^{-3}$.

Kinetics of labelling of nuclear and cytoplasmic rRNA with ${ }^{3} \mathrm{H}-\mathrm{Me}-\mathrm{methionine.} \mathrm{The} \mathrm{total} \mathrm{radioac-}$ tivity of the nuclear $37 \mathrm{~S}$ and $28 \mathrm{~S}$ as determined on the electrophoretic profiles (fig. 3 ) and of the cytoplasmic 26S and 18S RNA as determined on the sedimentation profiles (fig. 3 ) is plotted against incorporation time.

the $18 \mathrm{~S}$ rRNA than with the $26 \mathrm{~S}$ rRNA. The accumulation of radioactivity in both rRNA species in the cytoplasm is depicted in fig. 4.

This figure clearly shows that after short pulses with methyl-labelled methionine more radioactivity is associated with $18 \mathrm{~S}$ rRNA than with $26 \mathrm{~S}$ rRNA.

\section{DISCUSSION}

Several authors $[21 ; 22$ for review] have shown that in mammalian nuclei the initial event in the synthesis of ribosomal RNA is the formation of a large 45S RNA molecule. This molecule is present within the nucleus in fairly large amounts. Subsequent work has shown that this $45 \mathrm{~S}$ rRNA precursor is located in the nucleolus and forms an important RNA constituent of this organelle [8, 23].

The optical density profile of nuclear RNA from yeast, analysed on acrylamide gel (fig. $1 A$ ), shows the presence of several RNA components. The component with the greatest molecular weight is the 37S RNA species. It is present in relatively large amount. Kinetic studies on the labelling of nuclear RNA with ${ }^{14} \mathrm{C}$-uracil led us to the view that the initial event in the biosynthesis of ribosomal RNA is the formation of a $37 \mathrm{~S}$ precursor molecule [3]. Since only rRNA and its precursors, and tRNA are methylated [2-7], labelling experiments with ${ }^{3} \mathrm{H}$-methyl-methionine enabled us to study this question more accurately. Such experiments (figs 2, 3) show that the 37S RNA is indeed the earliest labelled species of RNA. The kinetics of incorporation, more extensively shown in fig. 4 , clearly indicate a precursor-product relationship between $37 \mathrm{~S}$ and $28 \mathrm{~S}$ RNA. There exists a relatively large nuclear pool of $28 \mathrm{~S}$ RNA, while no newly formed 18S RNA can be found in the nucleus (fig. 3). The relatively short times of labelling enabled us to observe the appearance of radioactivity in the two cytoplasmic rRNAs. The results presented in figs 3 and 4 show that more radioactivity was associated with the 18S rRNA than with the 26S rRNA.

From their studies on the in vivo methylation of rRNA in yeast Retèl et al. [7] concluded that the degree of methylation is very similar for $18 \mathrm{~S}$ and for $26 \mathrm{~S}$ rRNA, being about 1 methyl group per 70 nucleotides for both rRNAs. These authors have also shown that in addition to the ribose methylation, which takes place at the level of the first ribosomal precursor, an additional methylation occurs at later stages of the processing to mature rRNA. This additional methylation, which comprises about $20 \%$ of the total methylation, is predominantly base methylation. It may thus be expected that after very short periods of labelling an important part of the methyl label in cytoplasmic rRNA represents base methylation. Taking into account that the degree of methylation is similar for $18 \mathrm{~S}$ and $26 \mathrm{~S}$ 
rRNA, our results (figs 3, 4) can be interpreted as showing that the methyl-labelled $18 \mathrm{~S}$ rRNA enters the cytoplasm earlier than the methyl-labelled 26S rRNA. These data supplement and support our previous observations on the incorporation of ${ }^{14} \mathrm{C}$-uracil [3] from which we tentatively concluded that the newly formed $26 \mathrm{~S}$ rRNA enters the cytoplasm later than the newly formed $18 \mathrm{~S}$ rRNA. The accumulation of label in nuclear 28S RNA and the late appearance of label in the cytoplasmic $26 \mathrm{~S}$ rRNA strongly suggest that these RNA species are related. It is reasonable to assume that the nuclear $28 \mathrm{~S}$ RNA is a precursor of cytoplasmic $26 \mathrm{~S}$ rRNA.

It is worthwhile mentioning our observation of a rapidly labelled RNA component in the $20 \mathrm{~S}$ region (fig. 2). This could be an intermediate in the formation of $18 \mathrm{~S}$ rRNA. The presence of such a ' $20 \mathrm{~S}$ ' intermediate has been demonstrated in HeLa cells [8], in the salivary glands of the insect Chironomus tentans [24] in pea root and artichoke [25] and in the cellular slime mold Dictyostelium discoideum [26]. We do not observe the '20S' component in any of our nuclear preparations, however (see fig. 3). Due to the poor resolving power of sucrose gradient analysis it is impossible to distinguish 20S RNA from $18 \mathrm{~S}$ RNA in preparations of cytoplasmic RNA.

Leaver \& Key [27] and Rogers et al. [25] have shown that there exists a common precursor of the two mature rRNAs in plants. This precursor molecule is, just as in yeast, smaller than the corresponding precursor in mammalian cells. The authors [25, 27] suggest that this precursor or a smaller common intermediate is cleaved into the direct precursor molecules of the two mature rRNAs. The data of fig. 2 suggest that there exists such a smaller common intermediate (' $33 \mathrm{~S}$ ') molecule in yeast. The ' $33 \mathrm{~S}$ ' and ' $20 \mathrm{~S}$ '
RNA species (fig. 2), which may be intermediate in the formation of rRNA, are, however, quantitatively minor components. From the optical density and radioactivity patterns of nuclear RNA presented in the present paper and in a previous one [3], we can conclude that the ' $37 \mathrm{~S}$ ' and '28 S' species of rRNA are the ones that are most abundant in the nucleus. This is in good agreement with the data of others who describe the presence of at least two rRNA precursors in yeast, namely ' $40 S$ ' and ' $30 S$ ' [7], or ' $38 S$ ' and ' $30 \mathrm{~S}$ ' [2]. The existence of a ' $32 \mathrm{~S}$ ' intermediate in the formation of rRNA from a '37S' precursor in yeast has been demonstrated in a recent publication of Retèl \& Planta [28]. Their data also indicate the presence of a ribosomal precursor of still higher molecular weight, designated ' $42 S$ ', than we have found in our nuclear preparation.

Our data, together with the results of Taber \& Vincent [2] and Retèl [1, 7, 28] give a good picture of the synthesis and the processing of ribosomal RNA in yeast. Two major species of rRNA precursor molecules, $37 \mathrm{~S}$ and $28 \mathrm{~S}$, are located exclusively in the nucleus. The $37 \mathrm{~S}$ RNA is a common precursor of both $28 \mathrm{~S}$ and $18 \mathrm{~S}$ RNA. While the $18 \mathrm{~S}$ RNA rapidly leaves the nucleus, the $28 \mathrm{~S}$ RNA accumulates inside the nucleus and only later becomes converted into $26 \mathrm{~S}$ rRNA, which then enters the cytoplasm. An earlier entrance of $18 \mathrm{~S}$ rRNA in the cytoplasm is also observed in HeLa cells [21], in rat liver [29], in the protozoan Tetrahymena pyriformis [30] and in plants [25, 27, 31]. A question which is still unanswered concerns the site of synthesis of the ribosomal RNA precursors within the yeast nucleus. Inside the nucleus a structure called 'dense crescent' can be visualized which resembles the nucleolonema of the mammalian nucleolus in morphology and chemical nature [10]. The nucleolus is the site of synthesis of ribosomal 
RNA [22]. It is therefore tempting to believe that the dense crescent of the yeast nucleus is involved likewise in the synthesis of rRNA in yeast. Experiments, directed to answer this question, will be presented elsewhere [32, 33].

The present investigations were supported, in part, by the Netherlands Foundation for Chemical Research (S.O.N.) with financial aid from the Netherlands Organization for the Advancement of Pure Research (Z.W.O.).

\section{REFERENCES}

1. Retèl, J \& Planta, R J, Eur j biochem 3 (1967) 248.

2. Taber, $\mathbf{R}$ L \& Vincent, W S, Biochim biophys acta 186 (1969) 317.

3. Sillevis Smitt, W W, Nanni, G, Rozijn, T H \& Tonino, G J M, Exptl cell res 59 (1970) 440.

4. Moore, P B, J mol biol 18 (1966) 38.

5. Wagner, E, Penman, $S$ \& Ingram, U M, J mol biol 29 (1967) 371 .

6. Isaksson, L A \& Phillips, J H, Biochim biophys acta 155 (1968) 63.

7. Retèl, J, Bos, R C van den \& Planta, R J, Biochim biophys acta 195 (1969) 370 .

8. Weinberg, R A, Loening, U, Willems, $M$ \& Penman, S, Proc natl acad sci US 58 (1967) 1088.

9. Rozijn, T H \& Tonino, G J M, Biochim biophys acta 91 (1964) 105.

10. Molenaar, I, Sillevis Smitt, W W, Rozijn, T H \& Tonino, G J M , Exptl cell res 60 (1970) 148 .

11. Parish, J H \& Kirby, K S, Biochim biophys acta 129 (1966) 554.

12. Loening, U E, Jones, $\mathrm{K}$ W \& Birnstiel, M L, J mol biol 45 (1969) 353.
13. Schweizer, E, MacKechnie, C \& Halvorson, H O J mol biol 40 (1969) 261.

14. Loening, U E, Biochem j 113 (1969) 131.

15. - Ibid 102 (1967) 251.

16. Bishop, D H L, Claybrook J R \& Spiegelman, S, J mol biol 26 (1967) 373.

17. Choules, G L \& Zimm, B H, Anal biochem 13 (1965) 236.

18. Koch, P, Zeiss Mitt 4 (1968) 397.

19. Laarse, J D van der, Int $\mathrm{j}$ appl rad isot 18 (1967) 485.

20. Lewicki, P P \& Sinskey, A J, Anal biochem 33 (1970) 273.

21. Penman, S, J mol biol 17 (1966) 117.

22. Attardi, G \& Amaldi, P, Ann rev biochem 39 (1970) 183.

23. Muramatsu, M, Hodnett, J L, Steele, W J \& Busch, H, Biochim biophys acta 123 (1966) 116.

24. Ringberg, U, Daneholt, B, Edström, J E, Egyházi, E \& Lambert, B, J mol biol 51 (1970) 327.

25. Rogers, M E, Loening, U E \& Fraser, R S S, $J$ mol biol 49 (1970) 681 .

26. Iwabuchi, M, Mizukami, Y \& Sameshima, M, Biochim biophys acta 228 (1971) 693.

27. Leaver, C J \& Key, J L, J mol biol 49 (1970) 671

28. Retèl, J \& Planta, R J, Biochim biophys acta 224 (1970) 458

29. Willèn, R, Hoppe-Seyler's Z physiol Chem 351 (1970) 1141 .

30. Kumar, A, J cell biol 45 (1970) 623.

31. Tanifuji, S, Higo, M, Shimada, T \& Higo, S, Biochim biophys acta 217 (1970) 418 .

32. Sillevis Smitt, W W, Vermeulen, C A, Vlak, J M, Rozijn, T H \& Molenaar, I, Exptl cell res 70 (1972) 140.

33. Sillevis Smitt, W W, Vlak, J M, Molenaar, I \& Rozijn, T H. Submitted for publication.

Received July 20, 1971

Revised version received October 1, 1971 